\title{
Performance of State Level Public Enterprises of West Bengal: A Study on the Post Reform Era
}

\author{
Rama De \\ Assistant Professor of Commerce Department of Commerce, Tarakeswar Degree College, Hooghly.
}

\begin{abstract}
Public sector enterprises (PSEs) once were considered as the Temples of India. But gradually they became such a burden on the Government exchequer that in 1991 we had to take a U-turn on economic policy in general and on PSEs in particular. Since then a number of studies have been conducted to see how the Central Public Enterprises (CPSEs) are working in the changed scenario. But on State Level Public Enterprises (SLPEs), particularly of West Bengal there is hardly any study in post-reform era. In this background, this paper attempts to analyse the performance of SEPEs of West Bengal during the period from 2004-05 to 201011. Of three types of SLPEs, e.g, Departmental Undertakings, Public Corporation and Government Companies, the paper has however dealt with last two types of SLPEs as the structural and functional characteristic of first one are largely different from other two.
\end{abstract}

Keywords: West Bengal, Government exchequer, economic policy, Post reform era, Performance of SLPEs,

\section{Introduction}

Indian economy during the last several decades has undergone a dynamic change both in social and economic fields. The pressure emanating from international financial bodies, like the World Bank and the IMF has produced a series of economic forces which were both dysfunctional and catalytic for the domestic industry and the multinational corporations operating in India. Some companies have flourished and some have failed thereby. A good number of companies, particularly in public sector could not withstand the onslaught and became sick companies. Due to political and social considerations many ailing companies of private sector were subsequently taken over by the government under Industrial (Development and Regulations) Act, 1951 and thereafter nationalized. This led to accumulation of a large number of sick units in the administrative portfolio of both the State and Central Government. Problem is serious both for central PSUs and State Level Public Enterprises but this is much worse in case of SLPEs ${ }^{\cdot[1]}$

Public Sector Enterprises or Public Sector Undertaking is generic name for different organizational forms. 'PSE' or 'PSU are in fact public corporation established either by a separate enactment (as in the case of central public corporations) or established under enabling enactment of parliament like State Electricity Supply Act 1984.Secondly, Government. Companies, as defined in the Companies Act 2013 embrace both public limited companies and private limited companies. This again submits them to classification like companies taken over by Government. or those newly incorporated under the Companies Act. These three forms have characteristics features different from each other. Of these three, the Departmental Undertakings have in to way any commercial orientation and budgetary accounting is prevalent there. So in this paper we have analyzed the performance of other two types of PEs of West Bengal. In the next section, i.e, section-II we have made a review of literature, in section-III we have outlined the methodology that I have adopted. In section-IV some conceptual issues have been given. Section- $\mathrm{V}$ is the main section that has analysed one by one the capital position, rate of return, revenue generation and employment position in SLPEs of West Bengal. Finally in section-VI, I have tried to give some study-based recommendation for the improvement of the situation.

\section{Review Of Literature}

Most of the available literature deals with the analysis of the production, managerial efficiency, competitive strength, security of labour, achievement of social objectives of PEs in pre-reform era. And very few literature considers the impact of deregulation, delicensing, deservation, disinvestments in post-reform era. This has prompted the researcher to undertake the proposed study to reduce the gap in literature, both in quantitative as well as qualitative aspects, particularly relating to post-reform phenomena. The study on State Level Public Enterprises is also few and far between. However, the essence of some of the relevant works is briefly stated below.

2.1. Banerjee B (1987) also by his study concluded that in private sector also the main reasons for sickness were mismanagement faulty planning and bottleneck.

2.2. B. P. Mathur (1999) has also highlighted a strong justification for the state to withdraw from sick and loss making industries or those which are in non-core sector of the economy. 
2.3. Economic Survey (2001-02) has stated that the Government should no longer be operating commercial enterprises, the reason being the inefficient and loss making operations of existing public sector enterprises. Hence reforms have been initiated by the Government of India in PEs as part of the liberalization process.

2.4. Chakravorty (2002) having compared the performance of PEs with the magnitude of sickness of private sector, concluded that even after a full decade of liberalization, the private sector has failed to make the requisite breakthrough in infrastructure and basic services, so vital for the economy. It is certain therefore that public sector would continue to play a vital role in the Indian Economy.

2.5. R. K. Mishra \& B. Navin (2002) have identified the multiplicity of agencies which according to them, affects negatively the smooth functioning of PEs. They emphasize that a full-fledged autonomous agency has to be made accountable for the purpose to a body none other than Parliament.

2.6. Dr. Pradeep Singh (August-2008) has explained the need of performance evaluation with the help of value added reporting. According to him an enterprise may exist without profit but can not survive without adding value.

\section{Research Methodology}

The role of public sector has faced a radical change since 1991 liberalization era. Due to liberalization many changes took place in the basic industrial policy of our country. But to know the impact thereof, a period of at least five to ten years we must allow. So the period of my research work has started from 2004-05 to 201011. This paper has prepared up to date keeping in view the availability of secondary data.

The nature and background of operation of all such companies has brought under focus and the salient features of these operations have been underlined in the light of investments, employment, production and other factors.

Information has been collected from the CAG Report on the whole population of 90 SLPEs (72 working SLPEs and 18 non-working SLPEs) of West Bengal. This paper is prepared with the help of secondary data.

The secondary data have been collected from 'Economic Review' as well presented to the State Assembly, the report of the Comptroller and Auditor General of India, books, research articles etc.

Internet sources are also used as secondary sources of my work. Accounting tools have been used to analyze the data.

\section{Public Sector Enterprises (Pses)-Conceptual Issues}

There are various forms of PSEs and different lines of activities. These variations are shown in the chart below, indicating the flowchart of authority in the State Government. Companies.

\section{CHART}

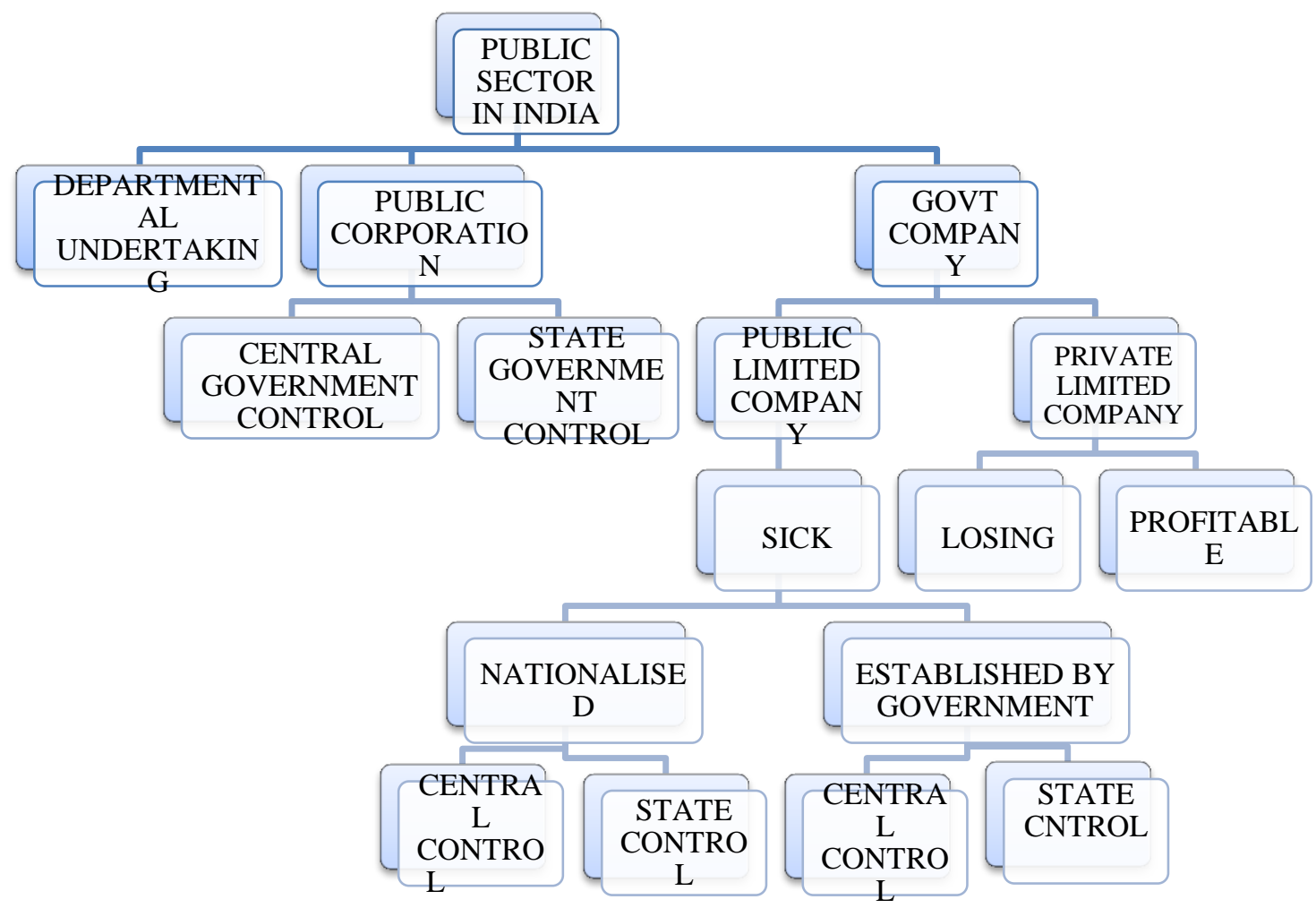


The CAG also makes a distinction among Departmental Undertaking Statutory Corporation and Govt.Companies under the control of the State Govt. as defined in the Companies Act 2013.These create complication with respect to their comparability. Governments control directly departmental undertakings and the Public Corporation. According to the companies act 2013 the government companies are established. They are under the legal control of the Central Government, while the operational control is vested on the State Government. State level companies are different from each other i.e. not uniform in nature. In fact there are many private limited Companies. They dropped the word private from their name under the waiver clause U/s 25 of the Companies Act.

The Departmental Undertakings under the control of the State Government are cinchona making Plant at Kalimpong and milk supply project at Haringhata to mention a few. They are run on commercial lines and their performance is judged by financial result. So the departmental undertaking is financed by annual appropriations from the treasury and its revenue are deposited into the treasury. The employees of a departmental undertaking are considered as civil servants. So their service condition relating to recruitment, retirement etc. are same as other civil servants.

Another form of Public Enterprise is Government Companies. A Government Company is a body corporate created under the general law viz Indian Companies Act 1956. It embodies features of a public limited company with whole of the capital Stock or 51 per cent or more owned by the Govt. The directors are appointed by the Government. It is advantageous because it allows flexibility and autonomy which is required for the successful operation of a commercial enterprise. But in reality most of the functions of a public sector company are vested in the Government and therefore the law regulating limited companies becomes more a fictions.

Public Corporation is another form of Public Sector Enterprise. It is formed by a special law defining its objectives, power and privileges. It derives revenues from the sale of goods and services and can also borrow from the Government and from public. Employees of public corporation are not civil servants.

The SLPEs are involved in a different of activities which are industrial development and financial promotion trading and marketing, contract and construction services, consumer goods and production of engineering goods to development of backward regions and weaker sections of society, and development and promotion of specific sections of industry viz agro industries tourism minerals and metals etc ${ }^{[2]}$. As we have stated earlier our study will concentrate on public corporations and Government companies only.

\subsection{Objectives of Indian Public Enterprises}

The formation of PEs in India mainly for removing problems which were prevalent in the preindependent era or after the attainment of independence. So the objectives of the first Industrial Policy Resolution (IPR) 1948 were for eliminating those problems .

In order to depict basic objectives of PEs, the relevant part of objectives of IPR-1948 are outlined below. The main objectives of IPR 1948 were as follows:

4.1.1 establish a social order where justice and equality of opportunities could and be assured to all the people.

4.1.2. promote rapid rise in the standard of living of the people through exploitation of latent and available resources of the country.

4.1.3. accelerate production to meet the needs of growing population and

4.1.4. provide more and more opportunities for employment ${ }^{[3] \text {. }}$

From the above objectives it is clear that this policy attempted to increase production as well as distribution of goods and services among the people through rapid industrialization to raise their standard of living. Thus the concept 'balanced growth' which has been regarded as important objectives of PEs during the major part of $20^{\text {th }}$ century was not given so weighatage. Again this motive of 'increased production' did not continue with the introduction of IIPR-PR 1951 which replaced the original IPR of 1948.This IPR 1956 attempted to give emphasis on 'socialjustice'instead of 'increase of production' because of honouring the intention of constitution of India.The main objectivs of IPR-1956 were to

a) accelerate the rate of economic growth

b) speed up industrialization

c) expand public sector and to build up a large and growing co-operative sector

d) remove regional disparities in setting up industries which exist today

e) prevent private monopolies of concentration of economic power.

From the above objectives it is clear that the motto of IPR-1956 was to remove economic disparities. Though a period of 50 years has passed but the public sector in India has more or less the same objectives. Hence there was no attempt to change the stated objectives of IPR-1956 in spite of issuing various policy i.e Industrial Licensing Policy,IPR-1977 and IPR-1980. However the Seventh Five Year Plan recognized that ' the growth of state enterprises will be moderated so that attention can be devoted to their consideration and improvement 
in performance ${ }^{[4]}$. Its two main objectives were profit and better performance. So improvement in performance must reflect in better profit. Profit is inevitable because "Profit is a stepping stone for attainment of leadership in the Industry ${ }^{[5]}$

The New Economic Policy which was introduced in the year 1991 has emphasized upon

this economic performance of PEs .So we should give here the main objectives of PEs

as depicted by Public Enterprises Survey in the year 2001-2002. The objectives are as follows:

To ensure rapid economic growth and industrialization of the country and create necessary infrastructure for economic development.

$>\quad$ To earn return on investment and thus generate resources for development

$>\quad$ To promote redistribution of income and wealth

$>\quad$ To create employment opportunities.

$>\quad$ To promote balanced regional development.

$>\quad$ To assist the development of small scale and ancillary industries.

$>\quad$ To promote import substitutions, save and earn foreign exchange for the economy.

\section{Performance Of Slpes Of West Bengal}

For Departmental Undertakings CAG (A.G OF West Bengal) treats the contribution made by Govt. as capital. In the case of Public Corporation also the long term loans as available to this units are treated as capital to imply that interest due on such capital every year is added back to profit. The interest charged by Govt. on this loan is lower than the market rate inviting critical comments from expert on the ground that undercharging of interest is not only unfair but also inefficient as to SLPEs in West Bengal, Sectorwise paid up capital and loans outstanding has been shown in the following Table.

TABLE

SECTORWISE PAID UP CAPITAL AND LOANS OUTSTANDING (Year-2008-09, 2009-10, 2010-11) (Working Government Companies)

\begin{tabular}{|l|l|l|l|l|l|l|}
\hline & $\begin{array}{l}2008-09 \\
\text { Rs. In Crore }\end{array}$ & $\begin{array}{l}2009-10 \\
\text { Rs. In Crore }\end{array}$ & $\begin{array}{l}2010-11 \\
\text { Rs. In Crore }\end{array}$ \\
\hline & $\begin{array}{l}\text { Paid up } \\
\text { Capital }\end{array}$ & $\begin{array}{l}\text { Loans } \\
\text { Outstanding }\end{array}$ & Paid up Capital & $\begin{array}{l}\text { Loans } \\
\text { Outstanding }\end{array}$ & Paid up Capital & $\begin{array}{l}\text { Loans } \\
\text { Outstanding }\end{array}$ \\
\hline Agriculture Allied & 79.67 & 127.57 & 80.25 & 132.87 & 81.89 & 138.07 \\
\hline Financing & 555.88 & 9359.03 & 603.38 & 8795.30 & 605.38 & 6257.35 \\
\hline Infrastructure & 242.73 & 30.16 & 243.63 & 73.64 & 243.09 & 79.45 \\
\hline Manufacturing & 2604.81 & 2986.46 & 2521.45 & 3233.98 & 2175.27 & 2887.70 \\
\hline Power & 7605.41 & 14385.75 & 8647.54 & 14363.12 & 8692.54 & 15089.51 \\
\hline Service & 38.77 & 476.10 & 39.37 & 503.76 & 39.43 & 614.06 \\
\hline Miscellaneous & 6.59 & 39.67 & 6.59 & 41.93 & 6.59 & 11844.19 \\
\hline Total & 10933.86 & 27404.74 & 12142.21 & 27144.50 & 25.35 \\
\hline
\end{tabular}

Source: Report of CAG (Commercial), Government of West Bengal, 2008-09,2009-10,2010-11 (Working Government Companies)

TABLE

SECTORWISE PAID UP CAPITAL AND LOANS OUTSTANDING (Year-2008-09, 2009-10, 2010-11) (Statutory Corporation)

\begin{tabular}{|c|c|c|c|c|c|c|}
\hline & \multicolumn{2}{|l|}{$\begin{array}{l}2008-09 \\
\text { Rs. In Crore }\end{array}$} & \multicolumn{2}{|l|}{$\begin{array}{l}2009-10 \\
\text { Rs. In Crore }\end{array}$} & \multicolumn{2}{|l|}{$\begin{array}{l}2010-11 \\
\text { Rs. In Crore }\end{array}$} \\
\hline & $\begin{array}{ll}\text { Paid up } \\
\text { Capital }\end{array}$ & $\begin{array}{l}\text { Loans } \\
\text { Outstanding }\end{array}$ & Paid up Capital & $\begin{array}{l}\text { Loans } \\
\text { Outstanding }\end{array}$ & Paid up Capital & $\begin{array}{l}\text { Loans } \\
\text { Outstanding }\end{array}$ \\
\hline Agriculture Allied & 7.62 & ---------- & 7.62 & ----------- & 7.62 & ------- \\
\hline Financing & 376.69 & 686.49 & 419.43 & 782.03 & 427.81 & 855.48 \\
\hline Infrastructure & ---------- & 96.34 & ------------ & 96.34 & ---------- & 96.34 \\
\hline Service & 31.33 & 633.86 & 31.33 & 739.30 & 31.33 & 774.36 \\
\hline Total & 415.64 & 1416.69 & 458.38 & 1617.67 & 466.76 & 1726.18 \\
\hline
\end{tabular}

Source: Report of CAG (Commercial), Government of West Bengal, 2008-09,2009-10,2010-11 (Working Statutory Corporation) 


\subsection{Capital Employed in SLPEs.}

The Capital Employed can be computed under two methods:

Under first method, it is the sum total of net fixed assets and working capital. Net fixed asset means gross fixed assets less accumulated depreciation. Again working capital means the excess of current assets over current liabilities.

Under second method, capital employed is indicated by investments in equity, long term debts and internal resources. Yearwise Working Government Companies 'Capital Employed has been shown in the Table.

\section{TABLE}

YEARWISE GOVERNMENT COMPANIES CAPITAL EMPLOYED

\begin{tabular}{|c|c|c|c|c|c|c|c|}
\hline \multicolumn{7}{|c|}{ WORKING GOVERNMENT COMPANIES } & (Rs. In Lakh \\
\hline Companies & $2010-11$ & $2009-10$ & $2008-09$ & $2007-08$ & $2006-07$ & $2005-06$ & $2004-05$ \\
\hline $\begin{array}{l}\text { Agriculture and } \\
\text { Allied }\end{array}$ & 1365 & 7135 & 6640 & 2261.41 & 3349.38 & 1568.71 & 2848.20 \\
\hline Financing & 1033710 & 1059494 & 1023579 & - & 1313419.46 & 1100359.86 & 903517.20 \\
\hline Infrastructure & 32541 & 22930 & 21778 & - & - & - & - \\
\hline Manufacturing & 411750 & 417233 & 439510 & - & - & - & - \\
\hline Power & 2625529 & 2446057 & 2228654 & $(4453.80)$ & 951759.45 & 822664.57 & 687812.18 \\
\hline Service & (41553) & $(24816)$ & $(18629)$ & - & - & - & - \\
\hline $\begin{array}{l}\text { Industrial } \\
\text { Development }\end{array}$ & - & - & - & $(3691.70)$ & $(4432.21)$ & $(7303.45)$ & $(3498.63)$ \\
\hline Engineering & - & - & - & $(12527.07)$ & $(19189.41)$ & $(17201.25)$ & $(14385.03)$ \\
\hline Electronics & - & - & - & 7986.97 & 6799.77 & 5709.07 & 4752.37 \\
\hline Textiles & - & - & - & (11835.08) & (7710.77) & $(12538.34)$ & (10968.01) \\
\hline $\begin{array}{ll}\text { Handloom and } \\
\text { Handicrafts }\end{array}$ & - & - & - & $(172.89)$ & 90.36 & $(77.21)$ & $\begin{array}{ll}(179.16) \\
\end{array}$ \\
\hline Forest & - & - & - & 2933.69 & 2382.72 & 2251.14 & 2389.14 \\
\hline Mining & - & - & - & (3928.58) & $(3401.62)$ & $(3309.44)$ & $(2920.55)$ \\
\hline Area Development & - & - & - & 9678.14 & 10247.27 & 21023.32 & 24436.59 \\
\hline $\begin{array}{l}\text { Development of } \\
\text { economically } \\
\text { Weaker section }\end{array}$ & - & - & - & 20.79 & 21.56 & 11.75 & 10.89 \\
\hline Public Distribution & - & - & - & 33953.61 & 34824.07 & 9549.47 & 9549.47 \\
\hline Tourism & - & - & - & 324.23 & 306.51 & 223.67 & 221.09 \\
\hline $\begin{array}{l}\text { Drugs, Chemicals } \\
\text { and } \\
\text { Pharmaceuticals }\end{array}$ & - & - & - & 7093.02 & 2621.43 & 592.72 & $(38.99)$ \\
\hline Transport & - & - & - & - & $(9921.25)$ & $(24929.45)$ & $(24937.25)$ \\
\hline Miscellaneous & $(9242)$ & (9648) & (2019) & - & $(3669.21)$ & (3341.34) & $(1957.21)$ \\
\hline Total & 4054100 & 3918385 & 3699513 & 27642.74 & 2277497.51 & 1895253.80 & 1576652.30 \\
\hline
\end{tabular}

Source: Report of the Comptroller and Auditor General of India (commercial), Government of West Bengal Above Table reveals that capital employed has increased from Rs. 1576652.30 in 2004-05 to Rs. 40,54,100/- in the year 2010-11.

Here capital employed represents net fixed assets plus working capital. Again fixed assets include capital work-in-progress. But in case of finance companies or corporation capital employed is computed as a mean of aggregate of the opening and closing balance of paid up capital, free reserves, bonds, borrowing. Here Financing Corporation included West Bengal Infrastructure Development Finance Corporation.

\subsection{Total Revenue of SLPEs}

This represents the top line of an enterprise. The income from mainstream operation and other yields are the total part of total revenue. The causes of lack of marketing drive, quality consciousness and target rate. All facts could be known from the total revenue scenario.

Total revenue scenario has shown in Table.

\section{TABLE}

YEARWISE SECTORWISE TOTAL REVENUE

\begin{tabular}{|l|l|l|l|l|l|}
\hline Year & $\begin{array}{l}\text { Working } \\
\text { Government } \\
\text { Companies }\end{array}$ & $\begin{array}{l}\text { Working } \\
\text { Statutory } \\
\text { Corporation }\end{array}$ & State G.D.P & $\begin{array}{l}\% \text { of } \\
\text { Turnover } \\
\text { to State } \\
\text { G.D.P }\end{array}$ & Total \\
\hline $2004-2005$ & 530724.92 & 462545.19 & 19024500 & 5.22 & 993270 \\
\hline $2005-2006$ & 511037.97 & 551266.11 & 20749500 & 5.12 & 1062304 \\
\hline $2006-2007$ & 705640.06 & 547441.18 & 23933400 & 5.24 & 1253081 \\
\hline $2007-2008$ & 624342.41 & 38746.56 & 27786900 & 2.39 & 663089 \\
\hline
\end{tabular}


Performance of State Level Public Enterprises of West Bengal: A Study on the Post Reform Era

\begin{tabular}{|l|l|l|l|l|l|}
\hline $2008-2009$ & 1682033.00 & 47559.00 & 31783700 & 5.44 & 1730415 \\
\hline $2009-2010$ & 2117257.00 & 49718.00 & 36762000 & 5.89 & 2166975 \\
\hline $2010-2011$ & 2278090.00 & 53818.00 & 46007100 & 5.07 & 2331908 \\
\hline
\end{tabular}

Source: CAG Audit Report (C0mmercial) 2004-05 to 2010-11

During the period 2004-05 to 2010-2011 the public sector recorded improvements on several fronts. The volume of sales increased from Rs.9,93,270/- lakh in the year2004-05 to Rs.23,31,908/- lakh in the year 2010-11. It would be seen from above table that PEs played a vital role in State GDP. Percentage of turnover to State GDP is around 5\% except in the year 2007-08.

\subsection{Scope of employment}

Only Public Sector Enterprises can give secured employment to all adult workers according to their level of skills and, training.Hence the role of the Public Sector Enterprises in contribution of overall employment situation is very significant.Thereby it is possible for SLPEs to fulfill social obligations.Our Constitution recogniges social and economic justice, such as labour welfare. The State Level Public Enterprises offer right wages, provide good working conditions and fulfill constitutional obligation. Table 2 -f represents the volume of work force in SLPEs.

TABLE

YEAR WISE MANPOWER OF WORKING GOVERNMENT COMPANIES AND STATUTORY CORPORATIONS.

\begin{tabular}{|c|c|c|c|c|c|c|c|}
\hline $\begin{array}{l}\text { Working } \\
\text { Government } \\
\text { Company }\end{array}$ & $\begin{array}{l}2010- \\
2011\end{array}$ & $\begin{array}{l}2009- \\
2010\end{array}$ & $2008-2009$ & $2007-2008$ & $2006-2007$ & $2005-2006$ & $2004-2005$ \\
\hline $\begin{array}{l}\text { Agriculture and } \\
\text { Allied }\end{array}$ & 6486 & 6453 & 6792 & 5871 & 5971 & 6038 & 6131 \\
\hline $\begin{array}{l}\text { Industrial } \\
\text { Development }\end{array}$ & - & - & - & 701 & 739 & 993 & 1102 \\
\hline Power & 31015 & 34040 & 34382 & 17695 & 8204 & 16364 & 16557 \\
\hline Financing & 373 & 376 & 374 & 119 & 115 & 115 & 119 \\
\hline Engineering & - & - & - & 1021 & 1335 & 1352 & 2014 \\
\hline Infrastructure & 809 & 486 & 518 & - & - & - & - \\
\hline Electronics & - & - & - & 482 & 532 & 622 & 688 \\
\hline Service & 8465 & 8426 & 8739 & - & - & - & - \\
\hline Textiles & & & - & 2375 & 2538 & 3209 & 2716 \\
\hline Manufacturing & 6377 & 6741 & 6609 & - & - & - & - \\
\hline $\begin{array}{l}\text { Handloom and } \\
\text { Handicrafts }\end{array}$ & - & - & - & - & 162 & 789 & 798 \\
\hline Forest & - & - & - & 1151 & 1176 & 1180 & 1241 \\
\hline Mining & - & - & - & 670 & 670 & 671 & 856 \\
\hline Area Development & - & - & - & 111 & 110 & 76 & 62 \\
\hline $\begin{array}{ll}\text { Development } & \text { of } \\
\text { economically } & \\
\text { weaker section } & \\
\end{array}$ & - & - & - & 16 & 15 & 11 & 13 \\
\hline Transport & - & - & - & 7677 & 7836 & 7874 & 8024 \\
\hline Public Distribution & - & - & - & 665 & 695 & 722 & 748 \\
\hline Tourism & - & - & - & 477 & 477 & 481 & 481 \\
\hline Drugs & - & - & - & 932 & 968 & 984 & 1224 \\
\hline Miscellaneous & 556 & 579 & 420 & 954 & 788 & 432 & 757 \\
\hline Total & 54081 & 57101 & 57834 & 40917 & 32337 & 42301 & 42531 \\
\hline $\begin{array}{l}\text { Working Statutory } \\
\text { Corporation }\end{array}$ & & & $2008-2009$ & $2007-2008$ & $2006-2007$ & $2005-2006$ & $2004-2005$ \\
\hline Power & - & - & - & - & 27031 & 27031 & 31120 \\
\hline Infrastructure & 198 & 199 & 204 & - & - & - & - \\
\hline Transport & - & - & - & 14420 & 15149 & 15744 & 16323 \\
\hline Financing & 533 & 524 & 530 & 434 & 460 & 463 & 468 \\
\hline $\begin{array}{ll}\text { Development } & \text { of } \\
\text { economically } & \\
\text { Weaker section } & \end{array}$ & - & - & - & 328 & 329 & 329 & 335 \\
\hline Tourism & - & - & - & - & - & 446 & 446 \\
\hline $\begin{array}{l}\text { Agriculture and } \\
\text { Allied }\end{array}$ & 100 & 116 & 140 & 158 & 189 & 209 & 241 \\
\hline Service & 12948 & 13648 & 14010 & - & - & - & - \\
\hline Total & 13795 & 14487 & 14884 & 15340 & 43158 & 44222 & 48933 \\
\hline
\end{tabular}


Source: CAG Report Government of West Bengal (Commercial).

\subsection{Rate of Returns ${ }^{[6]}$}

The Seventh Finance Commission (date of constitution - 23/6/1977 and date of submission of report Oct. 1978) declared for the first time the necessity for the non departmental SLPEs to earn return at a particular rate. The Eighth Finance Commission (Date of Constitution - 20/6/1982 and date of submission of the report April 1984.) and Ninth Finance Commission (Date of Constitution - June 1987 and date of submission of report December 1989) gave importance to this complex issues. They advised a five fold classification of these enterprises on the basis of their optimal ROR. According to their opinion five classification and their optimal rates of return are given below:-

\begin{tabular}{|l|l|}
\hline Classification of SLPEs & Optimal ROR \\
\hline Manufacturing & $12 \%$ \\
\hline Trading & $9 \%$ \\
\hline Service & $10 \%$ \\
\hline Financial & $8 \%$ \\
\hline Promotional and Welfare & $5 \%$ \\
\hline
\end{tabular}

But their suggestion could not be implemented due to certain practical constraints.. So again the SLPEs are divided into just three categories and the suggested ROR for them are given below:

\begin{tabular}{|l|l|}
\hline & Suggested ROR \\
\hline Commercial & $7.5 \%$ p.a \\
\hline Commercial cum Promotional & $5 \%$ p.a \\
\hline Promotional & $2.5 \%$ p.a \\
\hline
\end{tabular}

Commercial enterprises are mainly involved in manufacturing and allied operations. Rate of Return of 7.5\% p.a for commercial enterprises was suggested for providing enough leverage for sustenance and going in for expansion. Commercial cum promotional enterprises have two aspect i.e. they are involved in commercial functions and on the other hand they are involved also with promotional obligation quite naturally suggested ROR there is less. Again third category i.e, promotional enterprises fulfill social obligations of the Government. They are not primarily involved in profit making. So the suggested ROR there has been only $2.5 \%$. The Rate of Return actually earned by SLPEs in West Bengal has been shown in the Table.

TABLE

YEARWISE PAID UP CAPITAL, NET PROFIT/LOSS, RETURN ON CAPITAL EMPLOYED.

Rs. In Lakh

\begin{tabular}{|c|c|c|c|c|c|}
\hline & $\begin{array}{l}\text { Paid up } \\
\text { Capital }\end{array}$ & $\begin{array}{l}\text { Net } \\
\text { profit/Loss }\end{array}$ & $\begin{array}{l}\text { Total Return } \\
\text { on Capital } \\
\text { Employed }\end{array}$ & $\begin{array}{l}\text { Capital } \\
\text { Employed }\end{array}$ & $\begin{array}{l}\mathrm{ROC} \\
\mathrm{E}(\%)\end{array}$ \\
\hline \multicolumn{6}{|l|}{$2004-2005$} \\
\hline Working Government Company & 361177.57 & $(34905.96)$ & 119930.68 & 1576652.30 & 7.61 \\
\hline Working Statutory Corporation & 163417.59 & (46194.00) & 17657.06 & 455684.64 & 3.89 \\
\hline $\begin{array}{ll}\text { Non Working } & \text { Government } \\
\text { company }\end{array}$ & 3494.46 & $(5267.25)$ & (2736.43) & $(20151.31)$ & - \\
\hline $\begin{array}{ll}\text { Non Working } & \text { Statutory } \\
\text { corporation } & \\
\end{array}$ & NIL & NIL & NIL & NIL & \\
\hline TOTAL & 528089.62 & $(186367.21)$ & 134851.31 & 2012185.63 & 6.73 \\
\hline \multicolumn{6}{|l|}{$2005-2006$} \\
\hline Working Government Company & 427481.87 & $(24127.42)$ & 132145.31 & 1895253.80 & 6.95 \\
\hline Working Statutory Corporation & 164826.85 & $(43727.63)$ & 2608.48 & 401076.92 & 0.65 \\
\hline $\begin{array}{l}\text { Non Working Government } \\
\text { company }\end{array}$ & 3835.46 & (2713.94) & 5246.18 & $(19314.76)$ & - \\
\hline $\begin{array}{ll}\begin{array}{l}\text { Non } \\
\text { corporation }\end{array} & \text { Sorking } \\
\end{array}$ & NIL & NIL & $\mathrm{NIL}$ & NIL & \\
\hline TOTAL & 596144.18 & $(65141.11)$ & 39999.97 & 2277015.96 & 6.14 \\
\hline \multicolumn{6}{|l|}{$2006-2007$} \\
\hline Working Government Company & 488413.62 & 50456.12 & 203152.85 & 2277497.98 & 8.92 \\
\hline Working Statutory Corporation & 166635.85 & (43953.69) & 205241.17 & 2666798.17 & 7.70 \\
\hline
\end{tabular}


Performance of State Level Public Enterprises of West Bengal: A Study on the Post Reform Era

\begin{tabular}{|l|c|c|c|c|c|}
\hline $\begin{array}{l}\text { Non Working Government } \\
\text { company }\end{array}$ & 9012.52 & $(6757.12)$ & $(2657.22)$ & $(28912.36)$ & - \\
\hline $\begin{array}{l}\text { Non Working Statutory } \\
\text { corporation }\end{array}$ & - & $(510.68)$ & $(340.06)$ & $(1114.01)$ & - \\
\hline TOTAL 2007-2008 & 664061.99 & $(765.37)$ & 202243.89 & 4914269.78 & 7.67 \\
\hline Working Government Company & 567191.59 & 9848.45 & 156157.76 & 2335800.82 & 6.69 \\
\hline Working Statutory Corporation & 32763.84 & $(10026.31)$ & $(88.33)$ & 29285.46 & - \\
\hline $\begin{array}{l}\text { Non Working Government } \\
\text { company }\end{array}$ & 10341.19 & $(62.13)$ & 5320.16 & $(40331.50)$ & - \\
\hline $\begin{array}{l}\text { Non Working Statutory } \\
\text { corporation }\end{array}$ & - & $(510.68)$ & $(340.06)$ & $(1114.01)$ & - \\
\hline \multicolumn{1}{|c|}{ TO08-2009 } & 610296.62 & $(750.67)$ & 161049.53 & 2323640.77 & 6.93 \\
\hline $\begin{array}{l}\text { Working Government Company } \\
\text { company Working Government }\end{array}$ & 11304 & $(272)$ & 5182 & $(37515)$ & - \\
\hline $\begin{array}{l}\text { Non Working Statutory } \\
\text { corporation }\end{array}$ & - & $(511)$ & $(340)$ & $(1114)$ & - \\
\hline Working Statutory Corporation & 37660 & $(9063)$ & 809 & 36731 & 2.20 \\
\hline
\end{tabular}

From the above Table it is seen that in the year 2006-2007 rate of return on capital employed is highest i.e-7.67\%.The Eighth and Ninth Commission suggested ROR -7.5\% for Commercial SLPEs. The Tenth Finance Commission recommended for adoption of a modest rate of return on investment made in commercial, promotional and commercial cum promotional public enterprises at the role of $6 \%, 1 \%$ and $4 \%$ respectively. Above Table reveals that paid up capital for SLPEs of West Bengal as a whole increased from Rs.5,28,089/-

lakh tin the year 2004-05 to Rs 11,049,82 lakh with a percentage of rate of return. on capital employed from $6.73 \%$ to6.83\%.Again this Table shows that net loss of West Bengal SLPEs decreased from Rs.1,86,367 lakh in the year 2004-2005 to Rs.7721 lakh. In the year 2008-09.The $13^{\text {th }}$ Finance Commission (date of constitution November 2007 and date of submission of report December 2009) had recommended for a 5\% return on equity after drawing attention to the recommendation of the Tenth Finance Commission ${ }^{[7]}$. Year Wise debt equity ratio, net worth and return on equity of Government Companies and Statutory Corporations in West Bengal has been shown in Two Table respectively.

TABLE

Year Wise Profit after Tax, Loans Outstanding, Debt Equity Ratio, Net Worth, Return on Equity of Government Company in West Bengal

\begin{tabular}{|l|l|l|l|l|l|}
\hline Year & PAT & Total Loans Outstanding & Debt Equity Ratio & Net Worth & $\begin{array}{l}\text { Return } \\
\text { Equity }(\%)\end{array}$ \\
\hline $2004-05$ & $(349.05)$ & 18852.76 & $5.06: 1$ & 3725.84 & - \\
\hline $2005-06$ & $(241.27)$ & 17986.96 & $4.22: 1$ & 4262.31 & - \\
\hline $2006-07$ & 504.56 & 17781.54 & $3.60: 1$ & 4939.31 & 10.21 \\
\hline $2007-08$ & 98.48 & 23977.24 & $2.79: 1$ & 8594.00 & 1.15 \\
\hline $2008-09$ & 21.25 & 27404.74 & $2.46: 1$ & 11140.13 & 0.19 \\
\hline $2009-10$ & 21.96 & 27144.50 & $2.24: 1$ & 12118.08 & 0.18 \\
\hline $2010-11$ & $(164.69)$ & 25110.47 & $2.12: 1$ & 11844.56 & - \\
\hline
\end{tabular}

Source: CAG Report (Commercial) 2004-05 to 2010-11 
TABLE

Year wise Profit after Tax, Loans Outstanding, Debt Equity Ratio, Net Worth, Return on Equity of Statutory Corporations in West Bengal

\begin{tabular}{|l|l|l|l|l|l|}
\hline Year & PAT & Total Loans Outstanding & Debt Equity Ratio & Net Worth & $\begin{array}{l}\text { Return } \\
\text { Equity }(\%)\end{array}$ \\
\hline $2004-05$ & $(461.94)$ & 9565.22 & $5.81: 1$ & 1646.34 & - \\
\hline $2005-06$ & $(437.28)$ & 9966.59 & $5.99: 1$ & 1663.87 & - \\
\hline $2006-07$ & $(439.53)$ & 10575.32 & $6.28: 1$ & 1683.97 & - \\
\hline $2007-08$ & $(100.26)$ & 1323.56 & $3.76: 1$ & 352.01 & - \\
\hline $2008-09$ & $(90.63)$ & 1416.69 & $3.41: 1$ & 415.45 & - \\
\hline $2009-10$ & $(103.40)$ & 1617.67 & $3.53: 1$ & 458.21 & - \\
\hline $2010-11$ & $(97.11)$ & 1726.18 & $3.70: 1$ & 466.53 & - \\
\hline
\end{tabular}

Source: CAG Report (Commercial) 2004-05 to 2010-11

According to the observation of $13^{\text {th }}$ Finance Commission financial health of State Government in West Bengal is not good which can be dipicted from the above table. Because according to their recommendation return on equity should be 5\% irrespective of the category to which SLPE belonged.

Here Return of Equity is equal to the PAT/Net Worth. Here we calculate Net Worth from the debt equity ratio and total borrowing (i.e. Loan). From the year 2006-07 is remarkable in that year in case of Government Companies return on equity is more than 5\% i.e. 10\% but in other year it is far better 5\% or nil rate. But in case of Statutory Company return on equity in respect of every year is nil as it involves negative PAT. Hence we conclude that SLPEs in West Bengal do not follow the recommendation of $13^{\text {th }}$ Finance Commission except in the year 2006-07.

In case of Government Companies in the year 2004-05,2005-06 and 2010-11 PAT shows negative figure. But in the year 2006-07 to 2009-10 it has positive figure and the year 2006-07 is most important as in this year PAT is highest.

In case of Statutory Corporation PAT had a decreasing trend from Rs. 461.94 crores to Rs. 97.11 crores.

Again Net Worth had increasing trend in case of Government Company \& decreasing trend in Statutory Corporation.

6.1 Summary of work

VI. Summary Of Work And Conclusion

The performance of the State Level Public Enterprises in West Bengal has not been satisfactory as can be seen from the following table.

TABLE

Statement showing Performance of PSUs in West Bengal

\begin{tabular}{|l|l|l|l|l|l|l|l|}
\hline Year & $\begin{array}{l}\text { Profit } \\
\text { making } \\
\text { PSU }\end{array}$ & $\begin{array}{l}\text { Loss } \\
\text { making } \\
\text { PSU }\end{array}$ & $\begin{array}{l}\text { PSU at } \\
\text { BEP }\end{array}$ & $\begin{array}{l}\text { PSU arear in } \\
\text { accounts }\end{array}$ & Profit (Rs.) & Loss (Rs.) & $\begin{array}{l}\text { Net effect } \\
\text { (Net Loss) (Rs.) }\end{array}$ \\
\hline $2008-09$ & 34 & 32 & 03 & 03 & 538.73 & 608.11 & 69.38 \\
\hline $2009-10$ & 32 & 36 & 03 & 01 & 562.87 & 644.31 & 81.44 \\
\hline $2010-11$ & 30 & 40 & 01 & 01 & 550.58 & 812.38 & 261.18 \\
\hline
\end{tabular}




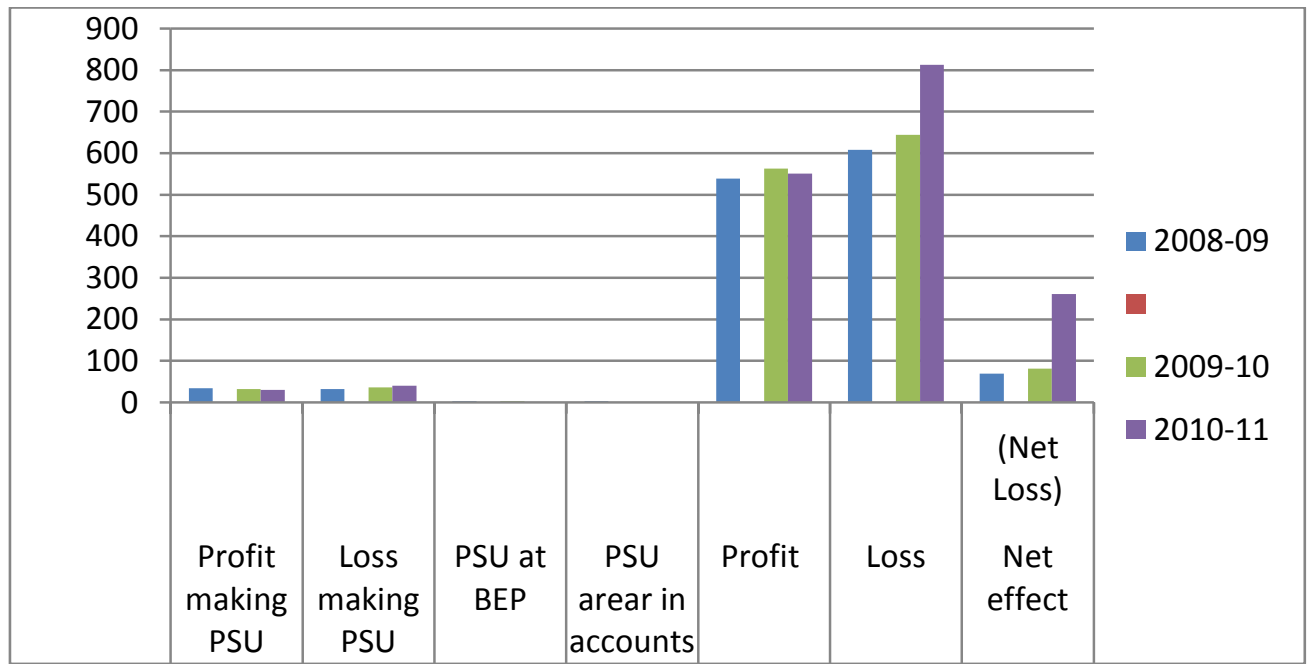

The above 'Table' reveals that no of profit making PSUs decreased and loss making working PSUs increased. As a result profit has increased from Rs. 538.73 corers in the year 2008-09 to Rs. 562.87 and again it has decreased to Rs. 550.58 corers. Whereas losses has increased from Rs. 608.11 in the year 2008-09 to Rs. 812.38 in the year 2010-11. Hence in each year net loss has increased from Rs. 69.38 corers to 261.18 corers in the year 2010-11.

Though SLPEs in West Bengal has tried to provide good working condition, better remuneration but it is not possible for SLPEs to fulfill social obligation which has shown in the table given in 5.1. From the analysis of that table scope of employment in the working statutory corporation is not good because no. of workers decreases from 48933 in the year 2004-05 to 13795 in the year 2010-11.

From the following table we can analyze that no. of PSUs is more or less same from the year 2001-02 to 2003-04. But they are fluctuating from the year 2004-05 to 2010-11. These fluctuations are due to either restructuring or closure of SLPs.

TABLE

STATEMENT SHOWING NUMBER OF WORKING AND NON-WORKING PSUS IN WEST BENGAL

\begin{tabular}{|c|c|c|c|c|c|c|c|}
\hline \multirow{2}{*}{ YEARS } & \multicolumn{3}{|c|}{ WOKING PSU } & \multicolumn{3}{|c|}{ NON-WORKING PSU } & \multirow[t]{2}{*}{$\begin{array}{l}\text { Total } \\
\text { PSUs }\end{array}$} \\
\hline & $\begin{array}{l}\text { COMPANIE } \\
\mathrm{S}\end{array}$ & $\begin{array}{l}\text { STATUTORY } \\
\text { CORPORATIO } \\
\mathrm{N}\end{array}$ & TOTAL & COMPANIES & $\begin{array}{l}\text { STATUTORY } \\
\text { CORPORATION }\end{array}$ & TOTAL & \\
\hline $\begin{array}{l}2010- \\
2011\end{array}$ & 63 & 09 & 72 & 17 & 01 & 18 & 90 \\
\hline $\begin{array}{l}2009- \\
2010\end{array}$ & 63 & 09 & 72 & 19 & 01 & 20 & 92 \\
\hline $\begin{array}{l}2008- \\
2009\end{array}$ & 63 & 09 & 72 & 22 & 01 & 23 & 95 \\
\hline $\begin{array}{l}2007- \\
2008 \\
\end{array}$ & 60 & 09 & 69 & 20 & 01 & 21 & 90 \\
\hline $\begin{array}{l}2006- \\
2007\end{array}$ & 56 & 09 & 65 & 19 & 01 & 20 & 85 \\
\hline $\begin{array}{l}2005- \\
2006\end{array}$ & 60 & 11 & 71 & 14 & --- & 14 & 85 \\
\hline $\begin{array}{l}2004- \\
2005 \\
\end{array}$ & 62 & 11 & 73 & 13 & --- & 13 & 86 \\
\hline $\begin{array}{l}2003- \\
2004\end{array}$ & 64 & 10 & 74 & 10 & --- & 10 & 84 \\
\hline $\begin{array}{l}2002- \\
2003 \\
\end{array}$ & 64 & 11 & 75 & 09 & --- & 09 & 84 \\
\hline $\begin{array}{l}2001- \\
2002\end{array}$ & 65 & 11 & 76 & 08 & --- & 08 & 84 \\
\hline
\end{tabular}

Source-_Report of the controller and Auditor General, Government of West Bengal (commercial) 


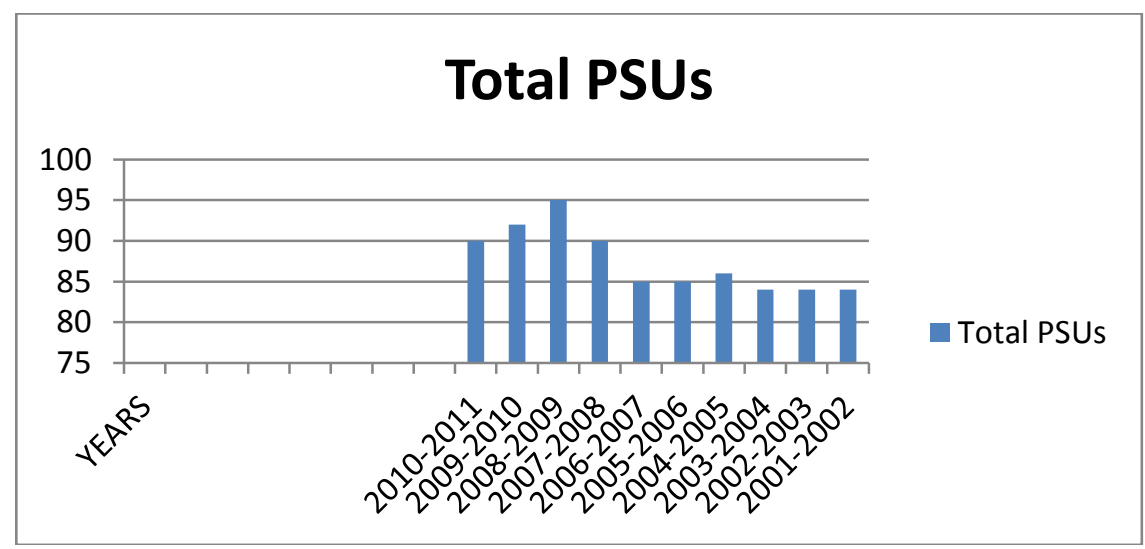

\subsection{Recommendation}

From the above it is seen that the overall as well as specific objectives of PEs have not been stated with clarity. Which could help to provide interlink ages between the enterprise and national economy. It is also concluded that non commercial objectives get emphasized at the cost of economic criteria. It is also necessary to balance the conflicting objectives.

It has been stated that there are different forms of public sector enterprises (PSEs). But it is not possible to suggest any form of organization which is best for administering public enterprises in all fields of economic activity. The choice of the form of organization for any enterprise will depend on a number of factors e.g. nature of enterprise, operational and financial requirement, past traditions, impact on national economy, managerial needs, general economic climate etc.

The company form of organization is not suitable for non-commercial functions where departmental organization is more appropriate. The corporation form is also suitable where the whole industry is organized in public sector and therefore involve question of overall industrial policy, resource allocation in aggregate terms as well as between the industry, pricing consumer interest and control.

The losses are attributable to various deficiencies in the functioning of PSUs. It is concluded from the Audit Reports of CAG (2003-04 to 2010-11) that some losses were controllable with better management. Hence there is a need for professionalism and accountability in the functioning of PSUs.

The Public sector in the future is expected to perform better and generate more revenues for re investment ans as a result they are not regarded as a public burden. So they will be considered as an effective tool in the hands of the Government to achieve of verity of socio economic objectives.

Considering the present working condition and social environment the following recommendation are made:

6.2.1. Qualified competent professional should be appointed for better financial management and control.

6.2.2. The autonomy of State Enterprises should be clear

6.2.3. The provision of the training of all the personal must be there so that they may contribute better skill and expertise.

6.2.4. Improved quality and production process should be made for betterment of revenue.

6.2.5. The marketing department should be enough competent which help to increased turnover.

6.2.6. Effective worker education program should be conducted regularly for better manpower utilization which achieves industrial peace.

6.2.7. Organization structure should be considered well to conduct better operation.

6.2.8. The remuneration package should be improved to retain skilled worker and decrease labour turnover ratio.

Books:

\section{References}

[1]. Ghosh Tarun Kanti "State Level Government Companies in West Bengal"

Reports:

[2]. Report of Comptroller and Auditor General (Commercial)

Books:

[3]. Sivayya K.V. and Das V.M.B (2001) “Indian Industrial Economy,” S. Chand and Company Ltd. New Delhi. 2001

Reports:

[4]. Planning Committee, Seventh Five Years Plan Government of India, Vol-2

Books:

[5]. Mallya N.N. (1971) "Public Enterprise in India" National publishing house Delhi.

Reports:

[6]. Report submitted by $7^{\text {th }}, 8^{\text {th }}, 9^{\text {th }}, 10^{\text {th }}$ and $13^{\text {th }}$ Finance Committee.

[7]. Survey on State Level Public Enterprises 2007-08, 2008-09, 2010-2011 